\title{
IMMUNOHISTOCHEMICAL DEMONSTRATION OF PROTEIN KINASE A IN THE RAT HIPPOCAMPUS
}

\author{
Gerd POEGGEL ${ }^{1}$, Hans LUPPA ${ }^{2}$, Heike BRANDT ${ }^{2}$, \\ AND ROLAND VETTER ${ }^{3}$ \\ Academy of Sciences ${ }^{1}$, Institute for Neurobiology and Brain Research, Leipziger Str. 44, \\ 3090-Magdeburg, GDR, Karl Marx University Leipzig ${ }^{2}$, Section of Biosciences, \\ Talstr. 33, 7010-Leipzig, GDR, and Academy of Sciences ${ }^{3}$, Central \\ Institute of Cardiovascular Research, Lindenberger Allee 70, \\ 1115-Berlin-Buch, GDR
}

Received for publication August 4, 1989 and in revised form September 26, 1989

\begin{abstract}
Protein kinase A (PKA) was localized in the rat hippocampus by an immunohistochemcal technique. The antibody was raised against the catalytic subunit of bovine heart PKA and cross-reacted with the brain enzyme, as could be revealed by immunoblotting. The strongest reaction was detected in the pyramidal and granular cell layers and in the lacunoso-molecular layer of the hippocampus formation. The reaction in the radial layer was restricted to the dendrites of the pyramidal cells. In the other regions mainly glial cells were stained.
\end{abstract}

Many cellular processes are regulated by phosphorylation reactions. Therefore, the cells dispose of a number of different protein kinases, which are regulated by different mechanisms. The protein kinase A (PKA) (EC 2. 7. 1. 37) is regulated by the intracellular concentration of cyclic AMP and seems to be the only receptor molecule for cAMP $(6,18)$. A lot of cellular reponses, like gene expression $(1,2,19)$, lipolysis (3), synaptic events (19) and so on are realized by the activation of the protein kinase A.

Whereas a great number of biochemcal data about the enzyme is available in literature, only little histochemical results have been published. We tried to localize the PKA in the rat hippocampal formation immunocytochemically to investigate the distribution of the enzyme between the different lyaers of this brain area.

\section{MATERIALS AND METHODS}

The catalytic subunit of bovine heart PKA was used as antigen for an immunization, as described by Poeggel et al. (16). The cross reactivity of the rabbit antiserum with rat brain PKA was tested by immunoblotting.

Adult Wistar rats were anaesthetized and perfused with $4 \%$ freshly prepared paraformaldehyde in $50 \mathrm{mM}$ phosphate buffered saline, $\mathrm{pH} 7.4$. After removing the brain, the hippocampi were prepared and immersion fixed for $24 \mathrm{hr}$. Fifty $\mu \mathrm{m}$

Abbreviantions: PKA: protein kinase A, PDE: cyclic nucleotide phosphodiesterase, ATP: adensine triphosphate, cAMP: cyclic 3', 5'-adenosine monophosphate. 
vibaratome sections were cut and washed overnight. The slices were incubated for $1 \mathrm{hr}$ in $1: 50$ diluted goat normal serum at room temperature and then transferred into the first antibody (dilution $1: 1000-1: 2000$ ) for $24 \mathrm{hr}$ at room temperature. This was followed by rinsing $3 \times 15 \mathrm{~min}$ with buffer and incubation in $1: 50$ diluted goatanti-rabbit anti-serum for $1 \mathrm{hr}$. The slices were washed again for $3 \times 15 \mathrm{~min}$ and incubated with 1:500 diluted PAP-complex for $2 \mathrm{hr}$ at room temperature. After a washing procedure of $3 \times 15 \mathrm{~min}$ the peroxidase was developed with diaminobenzidine according to Sternberger (20). The specificity of the reaction was controlled by comparison with the rabbit normal serum and by preabsorption of the antiserum with the antigen. All dilutions and washing procedures were performed with $50 \mathrm{mM}$ phosphate buffered saline $\mathrm{pH} 7.4$.

\section{RESULTS}

A strong immunoreaction was found in the pyramidal cell layer of the hippocampus (Figs. 1, 2) and in the granular cell layer of the dentate gyrus (Fig. 3). The somata of the neurons and their dendrites were stained. Furthermore, the lacunosomolecular layer (Fig. 4) was reactive. In the stratum oriens many glial cells were stained, which mostly contacted capillaries (Fig. 5). In some neurons the nuclei were stained by the antiserum (Figs. 1, 3). In the CA3-field only the pyramidal cell somata and dendrites were stained, whereas the mossy fibers did not contain any reaction product.

Control reaction with a rabbit normal serum (Fig. 6) and with the antiserum, preabsorbed with antigen, were negative.

\section{DISCUSSION}

The knowledge of the occurrence and distribution of enzymes, controlling main physiologial processes can help to increase our understanding of the regulation of cellular events. The protein kinase $\mathrm{A}$ is the only enzyme, functioning as a third messenger in the cAMP-cascade and increase or decreases the activity of its target proteins by phosphorylation processes $(4,12)$. The strongest immunohistochemical reaction of an antiserum against the catalytic subunit of PKA was found in the cellular layers of the hippocampi formation (Figs. 1-3) and in the region rich in synapses (Fig. 4). The somata of the neurons and their dendrites seem to contain the most substrate proteins of the PKA, like microtubules, histone $\mathrm{H} 1$, pyruvate kinase, $\mathrm{K}^{+}$-channels, proteins of the synaptic membranes, cholinergic receptors and much more $(9,10,12$, 19). The presence of PKA in the nucleus is often described $(7,8,11)$ and several nuclear substrate proteins were found $(5,17)$. This is in agreement with the nuclear localization of PKA-like immunoreactivity (Figs. 2, 3). Besides the strong neuronal reaction, glial cells were often stained by the antiserum, especially astroglial cells, contactiong capillaries (Fig. 5). The presence of other second messenger systems in glial cells as well as the presence of the cyclic nucleotide degradating enzyme was already histochemically described (13-15). Important glial cell-coupled processes seem to be under the control of the cyclic AMP system. In the CA3-field an immunohistochemical reaction was detected only in the somata and dendrites of the pyramidal cells, the mossy fibers were not stained. This points to a postsynaptic 


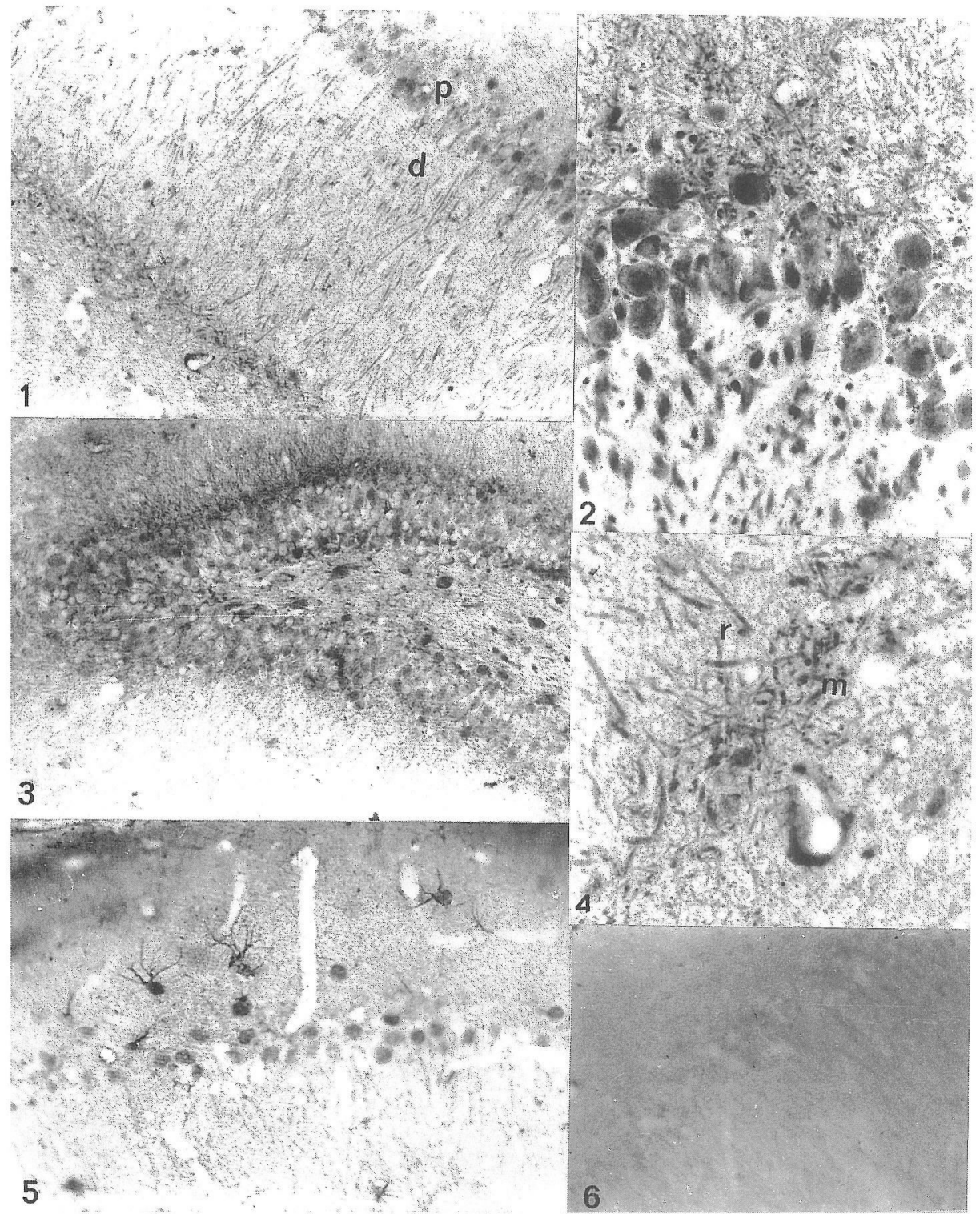

FIG. 1. PKA-like immunoreaction in the CA1-field of the rat hippcampus. Note the strong reaction in the pyramidal cells $(\mathrm{p})$, and their dendrites $(\mathrm{d}) . \quad \times 180$

FIG. 2. Immunoreaction in the pyramidal cells of the CA3-field. Note the reaction in somata and dendrites. $\times 440$

FIG. 3. Staining of the granular cells of the dentate gyrus. Note the different reaction of the nuclei. $\times 180$

FIG. 4. Reaction of the antibody in the radial layer $(r)$ and the lacunoso-molecular layer (m). Staining of the dedritic tree of the pyramidal cells and of a capillary. $\quad \times 530$

FIG. 5. Reaction of glial cells in the stratum oriens of the hippocampus. Note the contact with capillaries. $\times 320$

Frg. 6. Control reaction with rabbit normal serum. No specific staining occurs. $\quad \times 200$ 
localization and is also in agreement with the proposed association of PKA with a microtubule associated protein (MAP 2), which mainly occurs in dendrites $(4,10,12)$.

\section{ACKNOWLEDGMENTS}

The authors thank Mrs. Herold for her excellent technical assistance.

\section{REFERENCES}

1. Beebe, S. J., Koch, S. R., Chu, D. T. W., Corbin, J. D. and Granner, D. K.: Regulation of phosphoenolpyruvate carboxykinase gene transcription in H4 IIE hepatoma cells. Molec. Endocrinol. 1; 639-647, 1987.

2. Cherry, J. R., Johnson, T. R., Dollad, C., Shuster, J. R. and Denis, C. L.: Cyclic AMPdependent protein kinase phosphorylates and inactivates the yeast transcriptional activator ADR 1. Cell 56; 409-419, 1989.

3. Corbin, J.D., Cobb, C. E., Beebe, S. J., Cranner, D. K., Koch, S. R., Gettys, T.W., Blackmore, P. F., Francis, S. H. and Wells, J. N.: Mechanism and function of cAMP- and cGMP-dependent protein kinases. Adv. Second Mess. Phosphoprot. Res. 21; 75-86, 1988.

4. De Camilli, P.,Solimena, M., Moretti, M. and Navone, F.: Site of action of second messengers in the neuronal cytomatrix. In Intrinsic Determinants of Neuronal Form and Function; Neurology and Neurobiology, vol. 37, ed. by R. J. Sek and M. M. Black, Alan R. Liss Inc., New York, 1988, 487-520.

5. Fabisz-Kimowska, A. A., Lumlely-Sapanski, K. K., Halleck, M. S. and Schlegel, R. A.: Cellular copartmentalization of protein kinase activity during the cell cycle. Biochem. Cell. Biol. $65 ; 1070-1079,1987$.

6. Hofmann, F. and Schultz, G.: Regulation zellulärer Funktionen durch Proteinphosphorylierungen. Durg Res. 30; 1991-1995, 1980.

7. Joachim, S. and Schwoch, G.: Immunoelectron microscopic localization of catalytic and regulatory subunits of cAMP-dependent protein kinase in the parotid gland. Eur. J. Cell. Biol. 46; 491-498, 1988.

8. Kwast-Welfeld, J. and Jungmann, R. A.: Hormonal regulation of nuclear cAMP-dependent protein kinase subunit levels in rat ovaries. J. Biol. Chem. 263; 14344-14350, 1988.

9. Lohmann, S. M., De Camilli, P. and Walter, U.: Type II cAMP-dependent protein kinase regulatory subunit-binding proteins. Initiation and termination of cyclic uncleotide action. Meth. Enzymol. 159; 183-192, 1988.

10. Nairn, A. C., Hemmings, H. C. and Greengard, P.: Protein kinases in the brain. Ann. Rev. Biochem. 54; 931-976, 1985.

11. Nesterova, M. V., Barbashov, S. F., Aripdzhanov,A. A., Abdukimarov, A. and Severin, E. S.: Nuclear translocation and effect of cAMP-dependent protein kinase on transcription. Biochemja 45; 979-991, 1980.

12. Nestler, E. J. and Greengard, P.: Protein phosphorylation and the regulation of neuronal function. In Basic Neurochemistry, Molecular, Cellular, and Medical Aspects, 4th ed. by G. J. Siegel, B. W. Agranoff, R. W. Albers, and P. B. Molinoff, Raven Press, New York, 1989, p. 373-398.

13. Poeggel, G. and Luppa, H.: Histochemical demonstration of guanylate cyclase activity in the rat hippocampus by the elctron microscope. Basic. Appl. Histochem. in press, 1989.

14. Poeggel, G., Luppa, H. and Ludwing, A.: Histochemistry of cyclic nucleotide phosphodiesterase in nervous tissue. I. Enzymehistochemical investigations. Acta histochem. cytochem. 20; 375-380, 1987.

15. Poeggel, G., Luppa, H. and Ludwig, A.: Histochemistry of cyclic nucleotide phosphodiesterase in nevous tissue. II. Immunohistochemical investigations. Acta histochem. cytochem. 20; 381-386, 1987. 
16. Poeggel, G., Luppa, H., Ludwig, W. and Borneleit, P.: Production of an antiserum against cyclic nucleotide phosphodiesterase and its use for the immunocytochemical demonstration of this enzyme in rat cerbellum. Histochemistry 88; 513-518, 1988.

17. Riabowol, K. T., Fink, J. S., Gilman, M. Z., Walsh, D. A., Goodman, R. H. and Feramisco, J. R.: The catalytic subunit of cAMP-dependent protein kinase induces expression of genes containing cAMP-responsive enhancer elements. Nature 336; 83-86, 1988.

18. Saraswat, L. D., Ringheim, G. E., Bubis, J. and Taylor, S. S.: Deletion mutants as probes for localizing regions of subunit interaction in cAMP-dependent protein kinase. J. Biol. Chem. 263; 18241-18246, 1988.

19. Sieghart, W., Forn, J., Schwartz, R., Coyle, J. T. and Greengard, P.: Neuronal localization of specific brain phosphoproteins. Brain Res. 156; 345-350, 1978.

20. Sternberger, L. A.: Immunochemistry. Wiley \& Sons, New York, 1979. 